NBER WORKING PAPER SERIES

\title{
BANKING PANICS AND THE ORIGIN OF CENTRAL BANKING
}

\author{
Gary Gorton \\ Lixin Huang \\ Working Paper 9137 \\ http://www.nber.org/papers/w9137 \\ NATIONAL BUREAU OF ECONOMIC RESEARCH \\ 1050 Massachusetts Avenue \\ Cambridge, MA 02138 \\ September 2002
}

The views expressed in this paper are those of the authors and not necessarily those of the National Bureau of Economic Research.

(C) 2002 by Gary Gorton and Lixin Huang. All rights reserved. Short sections of text, not to exceed two paragraphs, may be quoted without explicit permission provided that full credit, including (C) notice, is given to the source. 
Banking Panics and the Origin of Central Banking

Gary Gorton and Lixin Huang

NBER Working Paper No. 9137

September 2002

JEL No. E5, G2

\section{ABSTRACT}

Gorton and Huang (2001) argue that private coalitions of banks can act as central banks, issuing private money and providing deposit insurance during times of panic. This lender-of-last-resort role depends upon banking panics occurring, because the threat of liquidation makes the private bank coalition incentive compatible, inducing banks to monitor each other. But, despite the evolution of private bank coalitions, government central banks and government deposit insurance schemes historically replaced the private bank coalitions. In this paper we ask why this transition from private arrangements to public arrangements occurred. We survey the historical and international evidence on panics, suggesting that Gorton and Huang (2001) are consistent with the evidence. Then, we extend Gorton and Huang (2001) to show the welfare improvement brought about by a government central bank replacing private bank coalitions as lender-of-last-resort. In particular, panics, while necessary for private coalitions to function, are costly because they disrupt the use of bank deposits as a medium of exchange. With government deposit insurance, panics do not occur, but the government must monitor banks. Such monitoring by the government is not as effective as private bank coalitions. We provide conditions under which the government can avoid the costs associated with panics by implementing deposit insurance and thereby raise social welfare.

Gary Gorton

The Wharton School

University of Pennsylvania and NBER

gorton@wharton.upenn.edu

Lixin Huang

Department of Economics

University of Pennsylvania

lixin2@ssc.upenn.edu 


\section{Introduction}

Central banking is a twentieth century phenomenon. According to Capie (1997), there were only eighteen central banks at the beginning of the $20^{\text {th }}$ century. By 1950 there were 59 central banks and by 1990 there were 161 . At the beginning of the $20^{\text {th }}$ century, the U.S. Federal Reserve System was not yet established; this would occur in 1914. The Bank of Canada came into being after the Great Depression, in 1934. Prior to the $20^{\text {th }}$ century central banks were established as institutions with monopoly rights over money issuance. But, if a critical element of central banking is the function of lender-of-last-resort, then these institutions generally did not become central banks until later, typically during the $20^{\text {th }}$ century. For example, although the Bank of England was established in 1694, it did not behave as a lender-of-last-resort until much later (see Lovell (1957)).

Explicit government deposit insurance is an even later development than lender-of-last-resort role of government central banks. In 1980 only sixteen countries had explicit deposit insurance programs; by 1999, sixty-eight countries had such programs (see Garcia (1999) and DemirigüçKunt and Sobaci (2000)). In the United States, deposit insurance was adopted in 1934 and in Canada in 1967. Today, in Germany, deposit insurance is still a private scheme, set up and run by the banks themselves. As with central banking generally, not only is deposit insurance late in developing, but also there is substantial cross-section variation in whether it is private or public.

While the spread of central banks in the $20^{\text {th }}$ century is likely related to the growth of activist monetary policy, it has been difficult to explain the origin of central banking. According to Goodhart (1985), central banks evolved as a response to the inability of the banks themselves to cope with panics. There was a natural evolution because some private banks assumed special roles in the capacity as the government's bank. These banks "evolved" into central banks. West (1974) and Timberlake (1978) focus on the origin of the Federal Reserve System, relating it to the real bills doctrine. Livingston (1986) argues that the Federal Reserve System came into being as part of the rise of finance capital, a manifestation of class struggle. Smith (1936) argues that central banks came into being as a tool to raise revenue for the government, but says little about the lender-of-last-resort role of central banks. In the case of Canada, Bordo and Redish (1987) argue that the origin of the Bank of Canada was essentially political; there was no economic rationale. Indeed, it is not an oversimplification to say that political explanations predominate over economic explanations in the literature on central banking. 
Why was central banking, by which we mean the lender-of-last-resort function, late in developing? Why did it develop in some countries first and not in others? Similarly, why is deposit insurance such a modern institution when panics have happened for some time in some economies? Gorton and Huang (2001) argue that the development of a central banking role as lender-of-last-resort, and deposit insurance, is intimately connected to the industrial organization of the banking system. Central banking first developed as a private response to problems in banking systems with many small, undiversified, banks. In such banking systems, uninformed depositors need to monitor their banks. Briefly, depositors know the state of the macroeconomy, but not the idiosyncratic state of their own bank. The way to check on a bank is to ask the bank to convert its demand deposits into currency. But, banks as a whole cannot do this and then the banking system faces liquidation. In response to this, banks form coalitions that can turn illiquid loan portfolios into liquid claims and convince depositors that the banks, as a group, are solvent, even if a depositor's particular bank may not be. This is the lender-of-last-resort function. But, these problems do not arise in banking systems with a small number of well-diversified banks. Such banking systems do not experience panics or high bank failure rates. Notably, as in the case of Canada, discussed below, they also did not develop central banks or adopt deposit insurance. These observations are important because they strongly suggest that banking panics are not a manifestation of an inherent problem with banks per se. We review the historical evidence further below.

The logic of the Gorton and Huang (2001) model closely follows the U.S. experience with panics. In the U.S., private bank clearinghouses issued private money called "clearinghouse loan certificates" during panics. These certificates functioned as a form of deposit insurance from the point of view of depositors because they served to convert claims on a single bank into claims on the group of banks in the coalition. For depositors to accept these certificates, they must be convinced that banks will coinsure each other. The coinsurance system only works if there are banking panics. Banking panics impose externalities on the banks doing well, forcing them to subsidize and monitor the banks that are not doing well. Monitoring via the coalition is more efficient than without the coalition because not all banks are closed in the panic. The coalition distinguishes banks doing well from those doing poorly, closing some of the latter banks and altering the incentives of other poorly performing banks. Banking panics play a critical economic function in enforcing the incentive compatibility of bank coalitions. Also, in order for the bank coalition to form during times of panic, the banks had to agree to mutually monitor each other to 
enforce reserve and capital requirements. This monitoring is the historical origin of bank examination and supervision.

To summarize, Gorton and Huang (2001) make three related points. First, banks are not inherently unstable institutions prone to panics. Rather, the likelihood of bank panics depends on the industrial organization of the banking system. A system with a few large, well diversified, banks is a very different system than one with many small, undiversified, banks. In the latter system, panics occur. Second, banking panics serve an economic function since they correspond to depositors monitoring banks, which induces coalitions to engage in self-monitoring. Third, private bank coalitions are a more efficient way for monitoring to occur, but the coalitions only function if panics occur. Private bank coalitions functioned as lenders-of-last-resort and provided a form of deposit insurance (as described below).

To assess these arguments we begin by surveying some of the historical evidence on the incidence of panics and the industrial organization of the banking system. We also look briefly at private bank coalitions. Private bank coalitions seem to have been most formally developed in the U.S., though other countries also had such coalitions, less formally, or in combination with a government central bank. The argument of Gorton and Huang suggests that government central banks would develop first as lenders-of-last-resort in countries where the banking system consisted of many, small, undiversified banks. These systems would experience panics and would form private bank coalitions. Economic historians have not explicitly looked at this rather complicated set of issues, but comparing Canada and the U.S. is informative, as these two systems display the contrasts of differing types of banking systems.

Next we examine some of the costs of banking panics that contemporary observers of panics highlighted. The costs concern disruptions of the transactions system during banking panics. It appears that during panics, when the value of bank liabilities comes into question, they stop functioning as a circulating medium. This evidence is reviewed as a prelude to our main theoretical argument, concerning why the government assumed the role of lender-of-last-resort, supplanting private bank coalitions.

The theoretical argument we propose begins from the point where Gorton and Huang (2001) leave off. In particular, Gorton and Huang (2001) do not explain why the government needs to take over the role of the private bank coalitions of clearinghouses. Indeed, they suggest that it is not obvious how the government can improve upon the private arrangements, lending credence to the view that political explanations are perhaps the most persuasive in explaining why the 
government introduced central banks. In this paper, we extend the Gorton and Huang's (2001) model to include a role for consumers using bank liabilities as a medium of exchange. This seems like a natural extension since bank liabilities do indeed serve this role. We show that, while panics can serve the role of disciplining banks by forcing coalitions to behave incentivecompatibly, panics disrupt the use of bank liabilities as a medium of exchange. This is costly. Since, according to this argument, a panic itself is costly, the government may improve welfare if panics can be avoided. But, panics are not just irrational runs on banks; they serve an economic function. So, if the government eliminates panics, with deposit insurance, then the government must take over the function of monitoring banks. The government may not be as effective at monitoring as the private coalitions, resulting in a cost. Whether the government central bank is superior to the private arrangements depends on this trade-off.

The paper proceeds as follows. In Section II we briefly review some of the historical and crosscountry evidence on the performance of banking systems and the history of panics. The goal of this review is to provide a context that a model should take into account. In particular, we summarize the experience of banking systems historically and internationally. In Section III we review Gorton and Huang's (2001) model and basic results. In Section IV we extend the model to include a role for consumers/depositors to use bank liabilities (bank notes or demand deposits) as a circulating medium of exchange. We then introduce a government central banking scheme and analyze the welfare implications of the government's scheme in contrast to the private bank coalition system. We provide conditions under which welfare improves under the government's scheme. Section V concludes.

\section{Panics and the Industrial Organization of Banking: The Historical and Cross Country Evidence}

In this section we briefly summarize research on banking history, in particular on the incidence and timing of banking panics in different countries, specifically in relation to the industrial organization of the banking industry. Then we compare the experiences of Canada to the U.S. to emphasize the differences. We briefly review the workings of bank coalitions, focusing on the American clearinghouse system. And finally, we discuss the question of disruption of the payments system during panics. 
To begin, we need a definition of a "banking panic." Calomiris and Gorton (1991) define a panic as an event in which bank debt holders (depositors) at many or even all banks in the banking system suddenly demand that their banks convert their debt claims into cash (at par) to such an extent that banks cannot jointly honor these demands and suspend convertibility. Note that this definition excludes events in which a single bank faces a run; a panic is a system-wide phenomenon. Also, cases where depositors seek to withdraw large amounts from the banking system, but banks can honor these withdrawals are not "panics," although the banking system may shrink significantly. Finally, note that the definition is specific enough to differentiate the event of interest from other events with nebulous names like "financial crisis" or "contagion" and so on. For a discussion of "bank panic" definitions in the literature, see Gorton and Winton (2001).

Using the above definition, Calomiris and Gorton (1991) identify six panics in the United States prior to 1865 , seven during the National Banking Era, and finally the panics during the Great Depression. In each case the phenomenon of interest is complicated, appears to have special circumstances, and seems to vary in important respects from other episodes, making any definition and inferences problematic. In fact, there are few observations of panics in any country, making hypothesis testing difficult. Nevertheless, some important empirical regularities have been found.

\section{A. Some Empirical Regularities about Panics}

Banking panics are more likely to occur in certain types of banking systems and at certain stages of the business cycle. Since the U.S. economy has the most experience with panics, for reasons that we discuss below, most of the research has focused on the U.S. The banking panic regularities are documented in a fairly large literature on the historical and international experience of banking panics, and we only briefly review it here. Bordo (1985, 1986), Calomiris and Gorton (1991), Calomiris (1993), and Gorton and Winton (2001) survey much of the literature and also provide some new evidence on the causes of panics. Andrew (1908a, 1908b), Sprague (1910), Wicker (1980, 1996, 2000), Donaldson (1993), Moen and Tallis (1992, 2000), Calomiris and Schweikart (1991), McGrane (1924), and White (1984), among many others, study individual U.S. panic episodes. 
The most important empirical regularity is that the industrial organization of the banking industry is a critical determinant of the propensity for an economy to experience panics. As summarized by Calomiris (1993): "International comparisons of the incidence and costs of banking panics and bank failures, and comparisons across regulatory regimes within the U.S., clearly document differences in banking instability associated with different regulatory regimes. The central lesson of these studies is that instability is associated with some historical examples of banking that had common institutional characteristics; it is not an intrinsic problem with banking per se ... the single most important factor in banking instability has been the organization of the banking industry" (p. 21). Basically, banking panics are much less likely to occur in banking systems in which there are a few relatively large, well-branched, and well-diversified banks. Bordo (1986) studies the experiences of six countries (U.S., U.K., Canada, Sweden, Germany, and France) over the period 1870 to 1933. One of Bordo's conclusions is that most severe cyclical contractions in all the countries are associated with stock market crises, but not with banking panics, except for the United States. He notes that: "In contrast with the U.S. experience, the five other countries in the same period developed nationwide branch banking systems consolidating into a very few large banks" (p. 230). Bordo (1985) surveys banking and securities market panics in six countries from 1870 to 1933 and concludes: "the United States experienced panics in a period when they were a historical curiosity in other countries" (p. 73). Grossman (1994) examines the experience of Britain, Canada, and ten other countries during the Great Depression to determine the causes of the "exceptional stability" exhibited by their banking systems. He considers three possible explanations: the structure of the banking system, macroeconomic policy and performance, and the behavior of the lender-of-last-resort. He concludes that banking stability is the product of exchange-rate policy and banking structure.

Cross section variation within the United States is also interesting because some states allowed branch banking while other states did not. States that allowed branching experienced lower failure rates in the 1920s and it was the smaller banks that were more prone to failure (see Bremer (1935) and White $(1983,1984))$. Studying this cross section of state experiences, Calomiris (1990) reaches the same conclusion about the importance of branching: "States that allowed branch banking saw much lower failure rates- reflecting the unusually high survivability of branching banks... From 1921 to 1929 only 37 branching banks failed in the United States, almost all of which operated only one or two branches. Branching failures were only 4 percent of branch-banking facilities, almost an order of magnitude less than the failure rate of unit banks for this period" (p. 291). Calomiris (1993) reviews more evidence. 
A second apparent regularity concerning banking panics is that there is an important business cycle and, possibly, seasonal component to the timing of panics. Panics come at or near business cycle peaks. The interpretation is not that panics caused downturns. There is not enough data to analyze that issue. Rather, the idea is that depositors received information forecasting a recession and withdrew in an anticipation of the recession, a time when bank failures were more likely. See Bordo (1986), Gorton (1988), Calomiris and Gorton (1991), and Donaldson (1992). While the relation of panics to the business cycle will be incorporated into the model below, the "regularity" is somewhat fragile as there are few observations of panics. Some have argued that there is also a seasonal factor in panics. The seasonal factor in the timing of panics is noted by Andrew (1907), Kemmerer (1910), Miron (1986), Donaldson (1992), and Calomiris and Gorton (1991), among others. But, Wicker (2000), for example, disputes the evidence. The seasonal factor seems less clear than the business cycle component.

\section{B. The Canadian and U.S. Banking Experiences}

A comparison of the U.S. and Canadian banking experiences from the middle of the $19^{\text {th }}$ century is an instructive example of the importance of industrial organization in banking and it's relation to central banking. This comparison is interesting because Canada is a system that historically has consisted of a small number of highly branched banks, in contrast to the American system of many banks that were not, until recently, branched across state lines, and sometimes not even within the state. Canada's central bank came into existence in 1935 and deposit insurance was adopted in the late 1960s. The differences between the two systems are striking and have often been commented upon (see the citations below).

The United States set up the National Banking system in 1863-64; fairly high capital requirements were imposed on federally chartered banks; there was a bond backing system for note issuance, reserve requirements, and other requirements, including in particular the prohibition of branch banking across state lines. Canada followed a very different set of banking policies, allowing branch banking, and imposing relatively fewer restrictions. The different national regulations led to very different banking systems. During the period 1870 to 1913 , Canada had a branch banking system with about forty chartered banks, each extensively branched. In 1890 the United States had more than eight thousand independent unit banks. See Williamson (1989). 
Haubrich (1990), Bordo, Rockoff, and Redish (1994, 1995), and White (1984), among others, study the different experiences of the two systems. In particular, there were high failure rates in the U.S. and low failure rates in Canada. Thirteen Canadian banks failed from 1868 to 1889 . Depositors lost very little in these cases (zero in eight of the cases) (see Vreeland, et. al., (1910), p. 219). During the same period, there were hundreds of failures in the U.S. (see the Comptroller of the Currency (1920)). In contrast to the U.S., there were no panics in Canada. Bordo, Rockoff, and Redish (1994) summarize the contrast in the experiences of the two systems: "There is an immediate and important difference between the Canadian and United States banking systems. The Canadian experience has been one of considerable stability. There has been only one major bank failure since World War I, and there were no failures during the Great Depression. In contrast, the American system has been characterized by a number of periods of instability. Rates of bank failures were high in the 1920s, and of course the entire system collapsed during the 1930s" (p. 325).

The comparative experience of the Great Depression shows that while there were few bank failures in Canada, the Canadian banking system did shrink. According to White (1984): "In Canada, from 1920 to 1929 , only one bank failed. The contraction of the banking industry was carried out by the remaining banks reducing the number of their offices by 13.2 percent. This was very near the 9.8 percent decline in the United States...In spite of the many similarities with the United States, there were no bank failures in Canada during the years 1929-1933. The number of bank offices fell by another 10.4 percent, reflecting the shocked state of the economy; yet this was far fewer than the 34.5 percent of all bank offices permanently closed in the United States" (p. 132). The Canadian banking system survived the Great Depression with few effects, while in the U.S., which had enacted the Federal Reserve Act in 1914, the banking system collapsed. Canada's central bank came into being in 1935, well after the Great Depression. Furthermore, Bordo and Redish (1987) argue that the introduction of the Central Bank of Canada was for political rather than economic reasons.

\section{Bank Coalitions in the U.S. and Other Countries}

Until the last few years, there have been a very large number of rather small, undiversified banks in the U.S. The U.S. also stands out as an outlier in the frequency of banking panics during its history. The research cited above strongly suggests that these two facts are linked. There is another, related fact, that is, U.S. banking history has been intertwined with the development of 
the private clearinghouse system. Clearinghouses are private associations of banks that formed in major cities, spreading out across the country during the $19^{\text {th }}$ century. Originally having roots in the payments system, these organizations developed into important institutions for monitoring banks and creating liquidity in times of banking panics. We briefly describe the functioning of these U.S. clearinghouses and then briefly mention other bank coalitions in other countries and contexts. On the U.S. clearinghouse system see Andrew (1908b), Cannon (1910), Gorton (1984, 1985), Gorton and Mullineaux (1987), Timberlake (1984), Sprague (1910), Moen and Tallman (2000), and Wicker (2000), among others.

The U.S. clearinghouse system developed over the course of the $19^{\text {th }}$ century. For purposes here the main point concerns the method that clearinghouses developed to turn illiquid loan portfolios into money, private money that could be handed out to depositors in exchange for their demand deposits during times of panic. Clearinghouse loan certificates originated in the interbank clearing system as a way to economize on cash during a panic. During a banking panic member banks were allowed to apply to a clearinghouse committee, submitting assets as collateral in exchange for certificates. If the committee approved the submitted assets, offered in exchange, then certificates would be issued only up to a percentage of the face value of the assets. The bank borrowing against its illiquid assets would have to pay interest on the certificates to the clearinghouse. The certificates could then be used to honor interbank obligations where they replaced cash, which instead could be used to pay out to depositors.

The clearinghouse loan certificate process is the origin of the discount window (and is described in detail in the above cited sources), and serves the same function. One difference, however, is that under the private clearinghouse system a member bank's application for loan certificates was secret. The identity of a weak member bank was not revealed. Notably, the loan certificates were the joint obligations of the clearinghouse member banks; the risk of member banks defaulting was shared by allocating member liabilities in proportion to member bank capital. Thus, the certificates were a risk-sharing device, where the members jointly assumed the risk that individual member banks would fail.

During the Panics of 1873, 1893, and 1907 the clearinghouse loan certificate process was extended, in increasingly sophisticated ways, in a radical innovation. In particular, the clearinghouse loan certificates were issued directly to bank depositors, in exchange for demand deposits, in denominations corresponding to currency. The amount of private money issued during times of panic was substantial. During the Panic of 1893 about $\$ 100$ million of 
clearinghouse hand-to-hand money was issued ( 2.5 percent of the money stock). During the Panic of 1907 , about $\$ 500$ million was issued (4.5 percent of the money stock). See Gorton (1985). If the depositors would accept the certificates as money, then the banks' illiquid loan portfolios would be directly monetized. As under the interbank arrangement of loan certificates, the certificates issued directly to the public were the joint liability of the clearinghouse, not the individual bank. In this way, a depositor who was fearful that his particular bank might fail was able to insure against this event by trading his claim on the individual bank for a claim on the portfolio of banks in the clearinghouse. This was the origin of deposit insurance.

The clearinghouses in the U.S. also developed bank examination and supervision methods, as well as reporting systems for information to be made public on a regular basis. (As previously mentioned, the revelation of information about individual banks was suspended during banking panics.)

The U.S. clearinghouse system was not the only private central bank-like institution. Before the U.S. Civil War, coincident with the beginnings of the clearinghouse system, the Suffolk Bank of Massachusetts was the focal point of a clearing system and acted as a lender-of-last-resort during the Panic of 1837. See Mullineaux (1987), Calomiris and Kahn (1996), Rolnick, Smith, and Weber (1998a, 1998b), and Whitney (1878).

Bank coalitions are also not unique to the United States. See Cannon $(1908,1910)$ for information on the clearinghouses of England, Canada, and Japan. While most countries did not experience banking panics as frequently as the U.S., there are many examples of bank coalitions forming on occasion in other countries as well. We mention a few examples. The Clearing House of Montreal was maintained by the Canadian Bankers' Association and, according to Watts (1972), was officially recognized in 1901 'as an agency for the supervision and control of certain activities of the banks' (p. 18). According to Bordo and Redish (1987) "the Bank of Montreal (founded in 1817) emerged very early as the government's bank performing many central bank functions. However, the Bank of Montreal never evolved into a full-fledged central bank as did the Bank of England (or the government's bank in other countries) perhaps because of the rivalry of other large Canadian banks (for example the Royal Bank)." See Watts (1972), Haubrich (1990), and Breckenridge (1910).

The pattern of the Bank of Montreal (and earlier precursors like the Suffolk Bank in the U.S.) in which the bank coalition is centered on one large bank, is quite common. Another common feature is the cooperation of a (perhaps, informal) coalition of banks with the government to 
rescue a bank in trouble or stem a panic. For example, major Canadian banks joined with the Canadian government to attempt a rescue of the Canadian Commercial Bank in March 1985. See Jayanti, Whyte, and Do (1993). Similarly, in Germany the Bankhaus Herstatt was closed on June 26, 1974. There was no statutory deposit insurance scheme in Germany, but the West German Federal Association of banks used \$7.8 million in insurance to cover the losses.

As mentioned in the Introduction, Germany is a particularly interesting case because it is a developed capitalist country where deposit insurance is completely private, being provided by coalitions of private banks (there is a coalition for each of the three types of banking institutions) following the Herstatt crisis of 1974 (see Beck (no date)). It is not compulsory and there is no public supervision. Germany is interesting in being so late in developing even a formal private coalition. But, the German banking system is one dominated by a few very large banks. Gorton and Huang (2001) label such systems Big Bank Systems and argue that such systems have a much lower incidence of panic and hence not much need for bank coalitions. In subsequent failures, the coalition of German banks worked in concert with public officials to resolve the situations (see Beck (no date)).

To summarize, private coalitions of banks have historically been important in functioning as lender-of-last-resort and in providing deposit insurance. Even today, private coalitions perform this function in many countries.

\section{The "Currency Famine" During Panics}

Banking panics may be costly because they disrupt the economy's transaction technology, which is based in large part on conducting trade with bank notes and bank deposits. Because agents in the economy doubt the value of bank circulating liabilities during panics, and because banks suspend convertibility, trade can no longer be conducted with bank liabilities, but only with currency. As a result of this, scared agents begin to hoard currency, refusing to deposit it into banks. This causes currency to go a premium. Companies cannot meet payrolls or conduct business; money substitutes begin to develop. The disruption of the transactions system has been described as a "currency famine." This description of a panic has not been formally studied by modern researchers, but corresponds to the observations of contemporary observers and early $20^{\text {th }}$ century researchers. We briefly provide more detail.

Sprague (1910) describes the aftermath of a panic in this way: "A far more serious cause of disturbance from the suspension of payments is the dislocation of the domestic exchanges. In 
making payments at a distance local substitutes for money will not serve. When the banks in one locality refuse to remit to banks elsewhere upon drafts and checks sent to them for payment business must soon come to a standstill” (p. 75). When bank liabilities are no longer acceptable as transactions media, agents in the economy start to hoard cash. Again, Sprague (1910) writes: "Uncertain whether the banks would provide the money they might shortly need, many persons began to discontinue paying into the banks cash received in the course of daily business" (Sprague, p. 68). Instead, people hoard currency. See Sprague (1910), Andrew (1908a, b), and Noyes (1909).

Such hoarding of currency had two effects. First, businesses cannot meet payrolls because there is not enough currency (see, e.g., Sprague (1910), p. 71). Sprague (p. 202) quotes the Commercial and Financial Chronicle, September 16, 1893:

The month of August will remain memorable as one of the most remarkable in our industrial history. Never before has there been such a sudden and striking cessation of industrial activity. Nor was any section of the country exempt from the paralysis; mills, factories, furnaces, mines nearly everywhere shut down in large numbers, and commerce and enterprise were arrested in an extraordinary and unprecedented degree. The complete unsettlement of confidence and the derangement of our financial machinery, which made it impossible to obtain loans or sell domestic exchange and which put money to a premium over checks, had the effect of stopping the wheels of industry and of contracting production and consumption within the narrowest of limits, so that our internal trade was reduced to very small proportions -- in fact, was brought almost to a standstill - and hundreds and thousands of men thrown out of employment. (p. 446 of the $\underline{\text { Chronicle). }}$.

Second, currency goes to a premium, which causes money substitutes to arise. See Sprague (1910), Andrew (1908a, b), and Noyes (1909). Andrew (1907a) and Sprague (1910) record the currency premia during various panics. During the Panic of 1907 the premium was as high as 4 percent. Again, Sprague writes: "While it is possible, though not probable, that the currency premium increased the domestic money supply, it is certain that it vastly increased the amount of money required for a given volume of transactions. Evidence for this conclusion is found in the apparent dearth of money which followed immediately the announcement that banks restricted payments" (p. 195-6). Andrew (1907b) describes and estimates the volume of substitutes for cash that arose during the Panic of 1907.

While the clearinghouse system developed over the course of the $19^{\text {th }}$ century, clearinghouse money issued during panics was not sufficient to eliminate the hoarding of cash and the consequent currency premia. The shock of the panic to the transactions system was sudden and uneven, effecting more distant areas more dramatically. Because of withdrawals from banks just 
prior to suspension of convertibility the money supply would drop, via the money multiplier. Then, the outstanding bank liabilities would no longer be acceptable. The extent of the consequent real effects on production and output has not been formally studied.

\section{The Model}

The evidence in Section II suggests that banking systems are not inherently unstable and that panics are related to the industrial organization of the banking system. Gorton and Huang (2001) present a model consistent with this evidence. In this section we review the details of their model and summarize their results, as a prelude to extending their analysis. There are two core assumptions in the model. First, there is asymmetric information: banks are better informed than their depositors. Second, banks may engage in moral hazard if their equity falls below a critical value. These are fairly standard assumptions. Not surprisingly these assumptions lead depositors to sometimes want to withdraw their bank deposits. Withdrawals may be inefficient because the bank may, in fact, be quite well off, but depositors do not know this.

\section{A. The Gorton and Huang (2001) Model}

The model economy has three dates, 0,1 , and 2, and two types of agents: consumers/depositors and bankers.

Bankers are unique in having the ability to locate risky investment opportunities. Also, only banks can store endowments (i.e., provide the service of safekeeping). There is a continuum of bankers. Each banker has capital $\beta$ and a measure one of potential depositors. Each bank has access to a riskless storage technology and to a risky investment technology. The fraction of the portfolio invested in the riskless storage technology is $\alpha$, subsequently referred to as "reserves." Investments in the risky projects have to be made at date 0 , and the returns are realized at date 2 . The date 2 return to a risky project depends on the state of the economy, which is a random variable, realized at date 1 . The return to a unit (of endowment good) invested in the risk project is $\widetilde{\pi}+\widetilde{r}$, that is, there is a systematic component, $\widetilde{\pi}$, and an idiosyncratic component, $\widetilde{r}$, to the return. $\tilde{\pi}$ is uniformly distributed in the interval $\left[\pi_{\mathrm{L}}, \pi_{\mathrm{H}}\right]$. For future reference, the probability density function of $\tilde{\pi}$ will be referred to as $A$, where $A \equiv \frac{1}{\pi_{H}-\pi_{L}}$. The idiosyncratic return for 
a risky project, $\widetilde{\mathrm{r}}$, is uniformly distributed in the interval $[0,2 \mathrm{M}]$. For future reference, the mean of $\widetilde{r}$ is denoted by $M$, i.e., $M=\frac{0+2 M}{2}$.

At date 1 , information about the date 2 return is realized, but there is asymmetric information between bankers and depositors. Depositors observe the realized state of the macroeconomy $(\pi)$, but they do not observe the realized state of their bank's idiosyncratic return, r. In addition to observing the macroeconomic state, each banker knows his own bank's state, $r$, and observes the realizations of other banks' idiosyncratic shocks at date 1. Idiosyncratic shock realizations at date 1 are not verifiable among banks, but realized cash flows at date 2 are verifiable. So, banks cannot write contracts with other banks contingent on idiosyncratic shocks at date 1 . At date 0 , we assume that the banks' choice of reserve level $\alpha$, and the level of bank capital $\beta$, are observable and verifiable.

There is a moral hazard problem in that bankers have an opportunity to engage in fraud at date 1 . Fraud is socially wasteful. If a banker engages in fraud, he gets a proportion $\mathrm{f}$ of the return (i.e. $\mathrm{f}(\pi+\mathrm{r}))$, where $\mathrm{f}$ is between 0 and 1 . The remaining amount, $(1-\mathrm{f})(\pi+\mathrm{r})$, is wasted and depositors receive nothing. Projects can be liquidated at date 1, yielding a constant return of Q, regardless of the state of the project. A risky project is indivisible when liquidation occurs. Although at date 0 , a banker can choose how much to invest in a risky project, at date 1 all the assets in a risky project must be liquidated if liquidation occurs.

Each depositor/consumer is endowed with one (indivisible) unit of perishable endowment good at date 0 . At date 0 each depositor can choose to consume or deposit in the bank. If they deposit in the bank, they can choose to withdraw at date 1 or date 2 (see the discussion in Gorton and Huang (2001) concerning the optimality of the deposit contract). Depositors have a subsistence level of 1. Their utility function is:

$u\left(c_{1}, c_{2}\right)=\left\{\begin{array}{cccc}c_{0}+c_{1}+c_{2} & \text { if } & c_{0}+c_{1}+c_{2} \geq 1 \\ -\infty & \text { if } & c_{0}+c_{1}+c_{2}<1\end{array}\right.$

where $c_{i}$ is consumption at date $i$. Depositors will consumer everything at a single date and will prefer to consumer later if they can consume the same amount of consumption goods.

Depositors' utility function implies that they will withdraw at date 1 if they anticipate that there is any chance that their bankers are going to engage in fraud. This is because they will receive less 
than one unit back if their banker engages in fraud, as explained below. Depositors deposit in a single bank.

Finally, bankers are risk neutral and they get the entire surplus from investment. The promised payment to depositors is equal to one, no matter when (at date 1 or date 2) depositors withdraw.

To make the problem interesting, Gorton and Huang (2001) assume that:

Assumption 1. $(1+\beta)(1-\mathrm{f})\left(\pi_{\mathrm{L}}+\mathrm{M}\right)<1$. This assumption assures that there is a potential moral hazard problem. Suppose the economy turns out to be in the worst possible state $\left(\pi_{\mathrm{L}}\right)$ at date 1 . If a banker with the mean return $\pi_{L}+\mathrm{M}$ engages in fraud, he will receive $\mathrm{f}(1+\beta)\left(\pi_{\mathrm{L}}+\mathrm{M}\right)$. If he does not engage in fraud, his payoff will be $(1+\beta)\left(\pi_{\mathrm{L}}+\mathrm{M}\right)-1$. The assumption that $(1+\beta)(1-\mathrm{f})\left(\pi_{\mathrm{L}}+\mathrm{M}\right)<$ 1 ensures that the banker has an incentive to engage in fraud.

Assumption 2. $\pi_{\mathrm{L}}>\mathrm{Q}>\mathrm{f}\left(\pi_{\mathrm{H}}+2 \mathrm{M}\right)$. In words, there is a dead weight loss if liquidation or fraud occurs.

Assumption 3. $\frac{\pi_{L}+\pi_{H}}{2}+M>1>Q$. In words, a risky project is more efficient ex ante than riskless storage, if there is no liquidation or fraud. However, if liquidation or fraud happens, then a risky project is dominated by investment in riskless storage.

Assumption 4. $(1+\beta) \mathrm{Q}>1$. That is, if depositors withdraw from their bank at date 1 , then their deposit contract can always be honored.

Depositors are rational in anticipating that their banker may have an incentive to engage in moral hazard in certain states of the world. If depositors anticipate that the banker is going to engage in fraud, they withdraw their deposits to prevent it. This corresponds to monitoring. Bankers can commit to not engage in moral hazard by holding reserves. The higher the level of reserves, the lower the probability that a bank run occurs. However, ex post, if the state of the economy is in a "good" state at date 1, then it would have been better to have invested in risky projects. The bankers' task at date 0 is to choose an optimal reserve level, $\alpha$ (the fraction of bank assets held in the riskless storage technology). This is the only choice variable.

Banks provide a way to transfer wealth from period to period since they are unique in being able to identify risky investment opportunities; consumers/depositors cannot find these opportunities. In addition, banks can provide a claim, a demand deposit, which is consistent with the subsistence 
requirement of consumers. Because of their utility functions, consumers need to be assured that their claim will be worth 1 unit and banks can satisfy this need. Implicitly, individual banks can diversify to this extent. The utility function is a reduced form for a consumer demand for a riskless trading claim (see Gorton and Pennacchi (1990)). The structure of preferences dictates the type of claim that banks will offer depositors: the bank must offer the right to withdraw deposits at face value at date 1, i.e., a demand deposit contract. This is for simplicity.

\section{B. Summary of the Results on Different Types of Banking Systems}

Gorton and Huang analyze three types of banking systems. The first is a system of independent unit banks. These are undiversified. The second is a system of a few large, diversified banks. The system of small independent Unit Banks, and that of Big Banks, as they are labeled, are essentially benchmark systems for comparison with the third system, which is one where the banks form a coalition.

In the system of independent, Unit Banks, the banks are small in the sense that a banker in charge of a Unit Bank can only manage one risky project. Such a banker cannot diversify the risk by dividing his asset portfolio into many risky projects. In the Unit Banking system, at date 1, depositors observe the state of the macroeconomy, $\pi$, and can calculate whether, given that state, there is a chance that their banker will engage in moral hazard. Because their utility functions are kinked and they will get minus infinity if consumption is less than one, depositors do not care about the likelihood of moral hazard occurring, but rather whether there is any chance of moral hazard occurring. If depositors find that there is a chance that bankers will engage in fraud (i.e. $\left.\pi<\frac{1-\alpha}{(1-f)(1+\beta-\alpha)}\right)$, then they withdraw all their savings. ${ }^{1}$ Since all the depositors receive the same macroeconomic information and all the banks are, from their viewpoint, homogeneous, if one bank suffers from a run, there are runs on all the other banks. Therefore, a panic occurs. In terms of the model, a banking panic is a date 1 event in which depositors at all banks seek to withdraw their deposits, and all banks are liquidated.

At date 0 , anticipating what will happen in different states of the world at date 1, bankers choose the optimal reserve level to maximize their expected payoff. On the one hand, bankers want to maximize investment in the risky projects because this is more profitable, but on the other hand, they want to avoid being prematurely liquidated in a banking panic at date 1 . When the reserve 
level is greater than or equal to $\bar{\alpha} \equiv \frac{1-(1+\beta)(1-f) \pi_{L}}{1-(1-f) \pi_{L}}$, banks have no incentive to engage in fraud even if the macroeconomy is in its lowest state $\pi_{\mathrm{L}}$. There is a unique optimal level of reserves in the interval $[0, \bar{\alpha}]$ that solves a Unit Bank's date 0 profit maximization problem.

The "Big Bank" system is a different form of industrial organization. A Big Bank is a bank with a portfolio of assets that has a realized return of $\pi+M$ at date 1 . In other words, its return is the systematic return plus the diversified idiosyncratic mean return, M. This is the essential point, namely, that the idiosyncratic risk is diversified away, implicitly by virtue of the bank's size via branching. Consequently, at date 1 , when the state of the economy is revealed, the return to a Big Bank's risky projects is also known. The state of macroeconomy is sufficient information for assessing the state of a Big Bank. As a result, depositors know for sure whether a Big Bank is going to engage in moral hazard or not. If they anticipate that their Big Bank will engage in fraud, they run on the Big Bank. Otherwise they wait until date 2 to withdraw.

Besides the fact that there is no information asymmetry with Big Banks, there is another very important difference. Big Banks have the flexibility to partially liquidate their portfolios at date 1. In fact, a Big Bank only needs to liquidate some of the risky projects when a bank run occurs. It is assumed that liquidation (and fraud) can occur at the project level. In order to deal with depositors' withdrawals at date 1, a Big Bank only needs to liquidate a fraction $\mathrm{x}$ of the risky projects such that $\alpha+(1+\beta-\alpha) \mathrm{xQ}$ is equal to 1 . Actually, however, a Big Bank can do even better if it can commit to not engage in fraud by liquidating some of the projects and holding the proceeds as additional reserves. Although the risky projects have idiosyncratic returns, for simplicity we assume that they have the same liquidation value $\mathrm{Q}$.

Suppose the Big Bank is to liquidate a fraction $\mathrm{x}$ of the risky projects. It should liquidate optimally, as follows. It will liquidate those projects that have realized idiosyncratic returns, $r$, in the interval $[0, \mathrm{x} 2 \mathrm{M}]$. The remaining $(1-\mathrm{x})$ fraction of projects has realized idiosyncratic returns $\mathrm{r}$ in the complementary interval: $[\mathrm{x} 2 \mathrm{M}, 2 \mathrm{M}]$. The average return on the remaining, i.e., nonliquidated, (1-x) fraction of projects is $\pi+\frac{x 2 M+2 M}{2}=\pi+(1+x) M$. If the Big Bank allows the remaining projects to continue without engaging in fraud, its payoff is $\alpha+(1+\beta-\alpha) \mathrm{xQ}+$ $(1+\beta-\alpha)(1-x)(\pi+(1+x) M)-1$. If the Big Bank engages in fraud on the remaining projects, its payoff will be $\mathrm{f}(1+\beta-\alpha)(1-\mathrm{x})(\pi+(1+\mathrm{x}) \mathrm{M})$. Therefore, to convince depositors that moral hazard will not occur the Big Bank has to liquidate a fraction $\mathrm{x}$ of the risky projects such that: $\alpha$ 
$+(1+\beta-\alpha) \mathrm{xQ}+(1+\beta-\alpha)(1-\mathrm{x})(\pi+(1+\mathrm{x}) \mathrm{M})-1 \geq \mathrm{f}(1+\beta-\alpha)(1-\mathrm{x})(\pi+(1+\mathrm{x}) \mathrm{M})$. The optimal $\mathrm{x}$ is the solution to the following problem:

$$
\begin{aligned}
& \operatorname{Max}_{x} \alpha+(1+\beta-\alpha) x Q+(1+\beta-\alpha)(1-\mathrm{x})(\pi+(1+x) \mathrm{M})-1 \\
& \text { s.t. }(1+\beta-\alpha)(1-\mathrm{x})(\pi+(1+\mathrm{x}) \mathrm{M})-1 \geq \mathrm{f}(1+\beta-\alpha)(1-\mathrm{x})(\pi+(1+\mathrm{x}) \mathrm{M}) \\
& \qquad \mathrm{x} \in[0,1] .
\end{aligned}
$$

Gorton and Huang solve this problem and provide the unique optimal fraction to liquidate at date 1. Then the date 0 problem is solved for choice of reserve level. For purposes here, note that in the Big Bank system, banks may experience withdrawals at date 1, but they do not fail, i.e., they are not liquidated. In the model there is no difference between the bank liquidating projects and holding the proceeds as reserves and withdrawals. In other words, the Big Bank system can be viewed as experiencing deposit withdrawals, but there are no bank runs or failures. The Big Bank system does not experience banking panics. The independent unit banks have bank runs, and failures, because each unit bank's project is indivisible when liquidation occurs.

In broad outlines, the distinction between the Big Bank system and the system of small independent Unit Banks corresponds to the difference between the Canadian and U.S. banking systems. As mentioned above, the Canadian system displayed fewer failures and no panics.

\section{The Setting With Bank Coalitions}

Finally, there is the case of bank coalitions. The basic idea for the coalition is as follows. Suppose that there are small independent Unit Banks at date 0. These small Unit Banks can decide to form a coalition at date 0 and the coalition can partially replicate the Big Bank in certain states of the world at date 1 . The coalition is defined by rules concerning date 0 reserve and capital levels, as well as rules indicating that, if there is a panic at date 1, then some banks are to be liquidated and the remaining banks must follow a prespecified sharing rule. (The details are in Gorton and Huang (2001).) At date 0, Unit Banks can get together to form a coalition and reach an agreement about their individual capital and reserve levels. Because the idiosyncratic shocks are not verifiable, and thus not contractible, the coalition has no power to force its members to comply with the rules and the member banks are free to quit at any time they want. The only requirement to become a member of the coalition at date 0 is to hold the required reserve level (and capital level). At date 1 the depositors cannot observe whether the coalition rules have been 
carried out or not. They can only observe whether the coalition liquidates some of the member banks and combines the assets and liabilities of the remaining member banks.

The operation of the coalition means to achieve two goals. First, by liquidating some of the member banks the coalition tries to inform depositors that the non-liquidated banks are in relatively more sound states. This partially alleviates the panic caused by the asymmetric information between the banks and depositors. Second, by pooling the liabilities the coalition tries to convince depositors that incentives to engage in fraud can be removed by monitoring and coinsurance among the remaining banks.

Gorton and Huang (2001) show that if there is no panic at date 1 then no bank coalition will operate. Banks will behave as Unit Banks. Because the rules of the coalition, adopted at date 0 , are not binding, banks are free to deviate from those rules. They can, in principle, adopt any set of rules concerning transfers among members (as long as such rules satisfy the budget constraint for the coalition). Without a panic, banks will always deviate from the proposed coalition rules. The banking panic creates an externality for banks that would not engage in the moral hazard problem, the "good" banks. If these good banks did not face the panic, they would have no incentive to monitor the banks that are going to engage in fraud, the "bad" banks. Because depositors cannot distinguish good banks from bad banks, all banks face the prospect of being liquidated. This creates the incentive for good banks to monitor bad banks.

Depositors anticipate that if they do not run on the banks, the coalition will not do anything to prevent member banks from engaging in fraud. So, they run all banks if and only if $\pi<\frac{1-\alpha}{(1-f)(1+\beta-\alpha)} \cdot{ }^{2}$ Once the depositors run the banks, the coalition has to operate to convince the depositors that it can remove the incentives to engage in fraud from some of its member banks and therefore there is no need to liquidate those banks.

Gorton and Huang prove the existence of a coalition equilibrium (see their definition). In this equilibrium, banks with idiosyncratic shocks $\mathrm{r} \in\left[0, \mathrm{x}^{*}(\alpha, \pi) 2 \mathrm{M}\right]$ are liquidated and these bankers are paid $\alpha+(1+\beta-\alpha) Q-1$, their outside option value of deviating from the coalition. The cut-off point $x^{*}(\alpha, \pi)$ is given by: $x^{*}(\alpha, \pi) \equiv \max \left\{0, \min \left\{1, \frac{1-\alpha-\pi(1-f)(1+\beta-\alpha)}{M(1-f)(1+\beta-\alpha)}-1\right\}\right\} .^{3}$ No member bank quits the coalition and no bank engages in fraud. For banks that are not liquidated there is a specified set of transfers. 
The coalition behaves as a lender-of-last-resort by monitoring and by providing insurance. Monitoring corresponds to liquidating bad banks, those with the worst idiosyncratic shock realizations. Member banks of type $\mathrm{r} \in\left[0, \mathrm{x}^{*}(\alpha, \pi) 2 \mathrm{M}\right]$ are liquidated. These banks would have engaged in fraud. The insurance comes from the transfers implemented among the non-liquidated banks. Member banks of type $\mathrm{r} \in\left[\mathrm{x}^{*}(\alpha, \pi) 2 \mathrm{M}, 2 \mathrm{M}\right]$ are not liquidated, but are assigned new debt obligations. Their original debt, i.e., face value of the demand deposits, was one. Banks with $r<\frac{1-\alpha}{(1-f)(1+\beta-\alpha)}-\pi$ have their debt reduced, so these banks are subsidized to entice them not to engage in fraud. This is efficient because their projects are worth more if they are continued, as long as they do not engage in fraud. Member banks with $r>\frac{1-\alpha}{(1-f)(1+\beta-\alpha)}-\pi$ have their debt increased, so these banks are being taxed to pay the subsidy to the low $r$ banks. Banks with high idiosyncratic shock realizations cannot be taxed too much, or they will engage in fraud. The transfers of the debt obligations must satisfy a budget constraint. The budget constraint limits how much insurance the coalition can provide and, therefore, determines the point at which member banks are liquidated.

At date 0 , each bank must decide whether to join the coalition and the coalition must determine the optimal reserve level $\alpha$. For comparison purposes later, the optimal reserve for the coalition is the solution of the following problem:

$$
\begin{aligned}
& \operatorname{Max}_{\alpha} \int_{\pi_{L}}^{\pi^{r}}[\alpha+(1+\beta-\alpha) x Q+(1+\beta-\alpha)(1-x)(\pi+(1+x) M)-1] d F(\tilde{\pi})+ \\
& \qquad \int_{\pi^{r}}^{\pi_{H}}[\alpha+(1+\beta-\alpha)(\pi+M)-1] d F(\tilde{\pi}) \\
& \text { s.t. } \quad \pi^{\mathrm{r}}=\frac{1-\alpha}{(1-\mathrm{f})(1+\beta-\alpha)} \\
& \quad \mathrm{x}=\max \left\{0, \min \left\{1, \frac{1-\alpha-\pi(1-\mathrm{f})(1+\beta-\alpha)}{\mathrm{M}(1-\mathrm{f})(1+\beta-\alpha)}-1\right\}\right\} . \\
& \quad \alpha \in[0, \quad \bar{\alpha}] .
\end{aligned}
$$

The coalition system is an intermediate case between the Unit Bank system and the Big Bank system. The similarity between the coalition system and the independent Unit Bank system is 
that we may observe bank failures (i.e., liquidations) when the economy is in a bad state. The similarity between the coalition system and the Big Bank system is that the coalition can monitor and insure member banks when the economy is in a bad state, while the Big Bank "monitors" itself by closing branches. The one unique feature associated with the coalition is that when a panic occurs, it suspends convertibility and issues certificates. This feature is important because it is a commitment made to depositors that the non-liquidated member banks will not engage in fraud and it provides incentives for member banks to monitor and insure each other.

\section{Summary}

With respect to efficiency, Gorton and Huang show that the Big Bank system is more efficient than the coalition system, which is more efficient than the independent Unit Banking system. Realistically, no economy is likely to exactly correspond to the Big Bank system, though some countries, e.g., Canada and Germany, may come close. Almost all economies may be expected to have some form of coalition with the degree of formality being related to the incidence of panics.

A key remaining issue concerns why private coalitions were replaced by the government in the form of deposit insurance and government banks acting as lender-of-last-resort. Gorton and Huang (2001) do not explain why government central banks replaced private bank coalitions. In fact, in their model, there is no obvious rationale for the government to step in and provide the lender-of-last-resort function unless the government has much more power than private agents, more resources than private agents, or there are costs to panics that have not been considered. They consider each of these possibilities in turn and conclude that the first two possibilities are unrealistic.

For example, if the government can simply intervene at date 1 and prevent fraud, then the government can improve welfare, compared to any of the private arrangements. But, this seems unrealistic. Nor is it realistic to assume to that the government can make transfers at date 2 contingent on the banks' idiosyncratic shock realizations. Governments are likely to be less informed than the banks themselves.

\section{Government Central Banks vs. Private Bank Coalitions}

An important role of banks is to provide a transaction medium. This role was not considered in the analysis above. In this section we extend the model to introduce a transactions role for bank 
liabilities. This is a natural extension, as bank liabilities do in fact function as a medium of exchange. We then analyze what happens to the transaction capabilities of bank money when there is a banking panic. We show that the transactions system based on bank money is disrupted in a costly way when there is a panic. Moreover, the problem we identify appears to be similar to that discussed by contemporary observers of panics, cited above. In particular, during panics the problem is the sudden disappearance to bank liabilities as an acceptable form of exchange. There is a "currency famine."

The incentive compatible functioning of the coalition requires the existence of panics. But, the bank coalition does not take the disruption of the transactions medium into account; it does not internalize this cost. Consequently, we are led to examine a role for government intervention in banking, specifically to replace the private bank coalitions. We consider two possible government policies. First, the government can set a level of required reserves that takes the costs of panic into account. Panics will still happen, but they will be less frequent than under the private system. With panics still occurring, the coalition will still function. A better system might be to eliminate panics all together. Thus, the second policy is one of deposit insurance. Under this system panics will be eliminated, but then the government must replace banks in monitoring. It may well be reasonable to assume that the government is not as effective as private banks in monitoring, so if the government monitors, then there is a cost, which may offset the benefits of eliminating panics. We will analyze the welfare implications of these various policies.

\section{A. Bank Liabilities as a Medium of Exchange}

We now turn to introducing a transactions role for bank liabilities. We extend the above model, as follows.

First, we introduce a new set of agents: sellers of goods. Sellers are located at different locations, indexed by $s \in[0, S]$, where $s$ is the distance from the consumers/depositors. Each seller can produce a consumption good at a constant cost of one unit. There are many sellers at each location, so the markets for consumption goods at different locations are competitive and the price of a consumption good is always one. We assume that the markets for consumption goods close shortly after date 1 and it takes time for consumers to find the consumption goods they prefer. Consumers cannot carry their date 0 endowments to the distant locations because their endowments are perishable. Neither can they trade the withdrawals from banks (at date 1 or date 2) for their preferred consumption goods because if they wait until date 1 there will be no time for 
them to locate the sellers before the markets are closed. Therefore the only way to buy the consumption goods at a distant location is to travel to the place at date 0 and pay for the goods with bank deposits. When a seller sells a good to a depositor/consumer, the seller will receive a claim on a distant bank. Clearing bank liabilities is assumed to be costless, as long as sellers accept them.

Next, to capture an idea of a division of labor and a preference over goods of different types, we assumed that the consumers/depositors prefer products purchased further away from their hometown. So, "s" also represents depositors' taste. We modify the depositors' utility function to include s. The utility function is now:

$u\left(c_{1}, c_{2}\right)=\left\{\begin{array}{clr}s+\left(c_{0}+c_{1}+c_{2}\right) & \text { if } \quad c_{0}+c_{1}+c_{2} \geq 1 \\ -\infty \quad \text { if } & c_{0}+c_{1}+c_{2}<1\end{array}\right.$

Note trade can only occur with bank deposits, so we have $\mathrm{s}=0$ if $\mathrm{c}_{0}>0$ or if $\mathrm{c}_{2}>0$.

As before, consumers/depositors have a subsistence level of one unit, but now they prefer larger $\mathrm{s}$. If $\mathrm{s}=0$, then the consumer/depositor is simply consuming one unit of the consumption good purchased at the home location, and the utility function is as before. According to the utility function, consumers have a taste for goods purchased some distance from the home location, so they must travel to make purchases. Similar ideas are modeled in Lucas (1980), Wallace (1988), and Gorton (1996). Note that $\mathrm{s}$ is not proportional to the quantity of consumption. In addition, we assume there is a round-trip traveling/search cost: $C(s)=\kappa s^{2}$, which is non-pecuniary. This cost is associated with shopping for the consumption good.

Implicitly, the notion of traveling to shop introduces three new ideas, though they are in the background. First, we implicitly introduce heterogeneous goods, because goods are now indexed by distance from the consumer/depositor's home location. Linking good-type to distance of search implicitly suggests that searching for goods that the consumer really likes is costly. This is captured by costs specified above. Second, goods can only be purchased with bank liabilities. We assume that consumers cannot carry their own endowments to the distant location and trade with sellers because their endowments are perishable. So, barter is ruled out, which seems quite realistic. Third, by assuming that markets close shortly after date 1 , we essentially assume that depositors have to find sellers before economic uncertainties are resolved and introduce the possibility that markets might be disrupted. At the time a consumer meets a seller, the information about the macroeconomy arrives. The information affects the sellers' decision about 
whether to accept bank deposits. Imagine that the consumer is at the distant location and there is a state of macroeconomy in which a panic is needed to prevent bankers from engaging in moral hazard. Then, the consumer's bank claim (note or deposit) will not be accepted by sellers because sellers sell to consumers from different places, and they cannot go to different places to run on different banks at the same time. If sellers cannot accept bank claims and run on banks, then depositors themselves have to go back to run on banks. Once they travel back and obtain loan certificates, depositors will not have a second chance to buy their preferred goods at distant locations because they have no time to find a seller before markets are closed. Therefore, while a panic is desired to prevent the moral hazard problem, it disrupts the markets for consumption goods at the same time.

Since the model is one of a representative agent, when there is a panic the consumers/depositors return to their banks and demand that their claims be redeemed for one unit of endowment. There is no issue of the consumers/depositors arriving at different times and having their claims honored sequentially. In fact, this would not matter in any case since all of their claims can be honored by assumption. Thus, the cause of panics in Diamond and Dybvig (1983), the sequential service constraint, is not an issue here. In the model here depositors' withdrawals are not motivated by beliefs about (sunspots that are believed to be related to) the actions of other depositors. Rather, they are only motivated by the desire to prevent the moral hazard problem, to monitor bankers. The assumed structure of preferences motivates depositors to avoid the moral hazard problem.

The sequence of events is recapitulated as follows:

1. At date 0 , consumers/depositors consumer their one unit of endowment of or save it by depositing it in the bank. They are promised one unit from banks at either date 1 or date 2 , at the consumer/depositor's discretion. They decide to search/travel to buy consumption goods (the cost is sunk) at a distant location.

2. At date 1, while depositors are at the distant location, the macroeconomic state is revealed.

3. If there is no need for a panic, consumers/depositors pay for their purchase with a bank liability drawn on their home location bank, which is then costlessly cleared. If a panic is needed, then (in equilibrium) depositors have to go back to their home location to liquidate their bank, receiving loan certificates and consuming home location products. 
Before we solve the banks' profit maximization program under different types of banking systems, we first solve for the consumers/depositors' optimal choice of s, the distance to travel at date 1, given that the promised payment from the banks is equal to one, and also taking as given the probability of panic $\eta$. The probability of panic, $\eta$, will be determined in equilibrium and will vary depending on the type of banking system we are in, as analyzed below. At date 1, consumers/depositors have one unit on deposit at the bank that can be spent on consumption goods. They choose s to solve the following optimization problem, recognizing the travel cost is given by $\mathrm{C}(\mathrm{s})=\mathrm{\kappa s}^{2}$ :

$$
\operatorname{Max}_{s}(1-\eta)\left(1+s-\kappa s^{2}\right)+\eta\left(1-\kappa s^{2}\right) .
$$

The solution is given by:

Lemma 1: Given a probability of panic of $\eta$, the optimal distance $s^{*}$ to travel is equal to $\frac{1-\eta}{2 \kappa}$, and depositors' utility $U\left(s^{*}\right)$ is equal to $1+\frac{(1-\eta)^{2}}{4 \kappa}$.

Proof: It is trivial to show that the objective function is strictly concave in s. The first order condition is: $(1-\eta)-2 \kappa s=0$. Therefore the optimal $s^{*}$ is equal to $\frac{1-\eta}{2 \kappa}$. Substituting in $\mathrm{s}^{*}$ to get the maximum value of the objective function $1+\frac{(1-\eta)^{2}}{4 \kappa} . / /$

For future reference, we note that:

Lemma 2: The optimal distance to travel and depositors' utility is decreasing in the probability of panic $\eta$.

The specification of preferences over distant goods, and the cost of traveling to these locations, has introduced a cost of a bank panic. Our interpretation is that the payments system in disrupted, causing a decline in utility. This is because when there is a banking panic, distant markets are effectively closed. The private coalition of banks will not consider this additional cost because 
they have to pay depositors one unit in any case. There is no way for the banks to extract the depositors' additional utility benefit from traveling to the distant locations to shop.

The cost of panics generates a possible reason for the government to intervene into the banking system, possibly eliminate panics, and improve social welfare. There are two distinct costs that arise. First, the possibility of panic introduces the chance that there will be no trade at the distant location. Since sellers cannot travel to run banks, they will not accept bank liabilities in exchange for goods if the macroeconomic state is in a panic state. No trade lowers utility. This effect is independent of the cost of traveling/searching, C(s). Second, because of the cost, $\mathrm{C}(\mathrm{s})$, consumers/depositors, recognizing that there is a chance of no trade occurring, reduce travelling/searching intensity s ex ante (Lemma 2).

We now proceed by analyzing the social welfare associated with different regulatory systems. Social welfare is defined as the sum of banks' payoffs and depositors' utility. As mentioned above, we analyze three banking systems. First, we recapitulate the private bank coalition system, analyzed by Gorton and Huang (2001). Next, we consider a system under which the government enforces reserve requirements that reduce the likelihood of panic at date 1. Finally, we analyze a system of government deposit insurance combined with the government monitoring banks at date 1 . We seek to learn how the government can improve social welfare.

\section{A. The Private Bank Coalition}

If there is no government intervention, bankers do not internalize the cost of market failure caused by panics. The optimization problem for the bank coalition is given in Gorton and Huang (2001). To be clear, the optimization problem is restated here. Note when $\pi$ is less than $\pi^{\mathrm{r}}$, panic occurs and the coalition is forced to liquidate a fraction $\mathrm{x}$ of its member banks.

$$
\begin{aligned}
& \operatorname{Max}_{\alpha} \int_{\pi_{L}}^{\pi^{r}}[\alpha+(1+\beta-\alpha) x Q+(1+\beta-\alpha)(1-x)(\pi+(1+x) M)-1] d F(\tilde{\pi})+ \\
& \qquad \int_{\pi^{r}}^{\pi_{H}}[\alpha+(1+\beta-\alpha)(\pi+M)-1] d F(\tilde{\pi}) \\
& \text { s.t. } \quad \pi^{r}=\frac{1-\alpha}{(1-f)(1+\beta-\alpha)}
\end{aligned}
$$




$$
\begin{aligned}
& x=\max \left\{0, \min \left\{1, \frac{1-\alpha-\pi(1-f)(1+\beta-\alpha)}{M(1-f)(1+\beta-\alpha)}-1\right\}\right\} \\
& \alpha \in[0, \bar{\alpha}] .
\end{aligned}
$$

Gorton and Huang (2001) solve the bank coalition problem to determine the optimal level of reserves. That solution does not change here. We use $\alpha^{\mathrm{C}}$ to denote the optimal reserve level. The following proposition gives the social welfare under the private bank coalition system.

Proposition 1: Let $\alpha^{C}$ denote the optimal reserve level for the private bank coalition system.

Panic occurs with probability $\eta^{\mathrm{C}}=\mathrm{A}\left(\pi^{\mathrm{r}}-\pi_{\mathrm{L}}\right)=\mathrm{A}\left(\frac{1-\alpha^{\mathrm{C}}}{(1-\mathrm{f})\left(1+\beta-\alpha^{\mathrm{C}}\right)}-\pi_{\mathrm{L}}\right)$. Social welfare is equal to

$$
\begin{aligned}
& \int_{\pi_{L}}^{\pi^{r}}\left[\alpha^{C}+\left(1+\beta-\alpha^{C}\right) x^{C} Q+\left(1+\beta-\alpha^{C}\right)\left(1-x^{C}\right)\left(\pi+\left(1+x^{C}\right) M\right)\right] d F(\tilde{\pi})+ \\
& \int_{\pi^{r}}^{\pi_{H}}\left[\alpha^{C}+\left(1+\beta-\alpha^{C}\right)(\pi+M)-1\right] d F(\tilde{\pi})+1+\frac{\left(1-\eta^{C}\right)^{2}}{4 \kappa}, \text { where } \pi^{\mathrm{r}}=\frac{1-\alpha^{\mathrm{C}}}{(1-\mathrm{f})\left(1+\beta-\alpha^{\mathrm{C}}\right)}, \\
& x^{C}=\max \left\{0, \min \left\{1, \frac{1-\alpha^{C}-\pi(1-f)\left(1+\beta-\alpha^{C}\right)}{M(1-f)\left(1+\beta-\alpha^{C}\right)}-1\right\}\right\} .
\end{aligned}
$$

Proof: If $\alpha^{\mathrm{C}}$ is the optimal reserve level, the panic occurs when the macroeconomic state $\pi$ is less than the critical value $\pi^{\mathrm{r}}=\frac{1-\alpha^{\mathrm{C}}}{(1-\mathrm{f})\left(1+\beta-\alpha^{\mathrm{C}}\right)}$. So the probability that panic occurs is $\eta^{\mathrm{C}}=\mathrm{A}\left(\pi^{\mathrm{r}}-\pi_{\mathrm{L}}\right)=\mathrm{A}\left(\frac{1-\alpha^{\mathrm{C}}}{(1-\mathrm{f})\left(1+\beta-\alpha^{\mathrm{C}}\right)}-\pi_{\mathrm{L}}\right) . \quad$ Therefore depositors, utility is equal to $1+\frac{\left(1-\eta^{\mathrm{C}}\right)^{2}}{4 \kappa}$, and social welfare is just the sum of the banks' surplus and the depositors' utility. //

Because the individual banks and their coalition cannot extract the additional utility that depositors get from consuming goods produced at distant locations, the cost of panic is not internalized. The proposition simply calculates the implied probability of panic for that solution so that social welfare can be calculated. We will use this as a benchmark against which to compare the government solutions. 


\section{B. A Government Required Reserve Level}

Since the private bank association system fails to internalize the cost of market failure, i.e., the failure of the transaction media, the government can internalize the cost by imposing a minimum reserve level for banks at date 0. By imposing such a required reserve level, the government forces banks to hold more reserves, and thereby lowers the probability of panic. This results in a decrease in the bankers' payoff and an increase in the depositors' utility. The government chooses the reserve level, $\alpha$, to solve the following problem:

$$
\begin{aligned}
& \operatorname{Max}_{\alpha} \int_{\pi_{L}}^{\pi^{r}}[\alpha+(1+\beta-\alpha) x Q+(1+\beta-\alpha)(1-x)(\pi+(1+x) M)-1] d F(\tilde{\pi})+ \\
& \int_{\pi^{r}}^{\pi_{H}}[\alpha+(1+\beta-\alpha)(\pi+M)-1] d F(\tilde{\pi})+1+\frac{(1-\eta)^{2}}{4 \kappa} \\
& \text { s.t. } \quad \pi^{\mathrm{r}}=\frac{1-\alpha}{(1-\mathrm{f})(1+\beta-\alpha)} \\
& \quad \mathrm{x}=\max \left\{0, \min \left\{1, \frac{1-\alpha-\pi(1-\mathrm{f})(1+\beta-\alpha)}{\mathrm{M}(1-\mathrm{f})(1+\beta-\alpha)}-1\right\}\right\} . \\
& \eta=\mathrm{A}\left(\pi^{\mathrm{r}}-\pi_{\mathrm{L}}\right)=\mathrm{A}\left(\frac{1-\alpha}{(1-\mathrm{f})(1+\beta-\alpha)}-\pi_{\mathrm{L}}\right) \\
& \alpha \in[0, \quad \bar{\alpha}] .
\end{aligned}
$$

The solution is given by:

Proposition 2: The government's objective function has a unique maximum in the interval $[0, \bar{\alpha}]$. Moreover, if $\kappa$ is big enough, the government's objective function is strictly concave in $\alpha$ and there exists a unique solution, $\alpha \in[0, \bar{\alpha}]$, that solves the government's optimization problem.

Proof: See Appendix.

Since the government does take consumers/depositors' welfare into account, unlike the private profit maximization problem of the banks, it is not surprising that we get the following result. 
Proposition 3: Government intervention with the required reserve level dominates the private coalition system by imposing a higher reserve level.

Proof: See Appendix.

By imposing a required reserve level, the government decreases the probability that panic occurs, but cannot eliminate panics. Panics are still needed for bankers to monitor and coinsure each other when the economy is in low states, though the set of low states over which there be a panic is reduced.

Perhaps it would be better to eliminate panics altogether. If panics are to be eliminated, then some agent must still monitor the banks. Since the role of panics is to cause banks to monitor each other, the elimination of panics must, at the same time, involve a scheme for bank monitoring. Suppose the government were to take over the task of monitoring the banks. If the government can monitor the banks, it can prevent bankers from engaging in fraud and there is no need for depositors to run banks. In other words, the government can make the depositors' deposits safe by monitoring the banks. This is equivalent to the government providing deposit insurance. We proceed to analyze social welfare under such a deposit insurance system.

\section{Deposit Insurance}

Suppose the government insures that deposits will always be worth one unit. To make this claim credible the government must monitor banks. Reasonably, the government may have a disadvantage in collecting information about the banks' idiosyncratic shocks, r. To reflect this disadvantage, we assume there is a cost $\mathrm{C}$ for the government to learn the banks' idiosyncratic shocks and to implement transfers between banks. Let us suppose that each bank holds a reserve level $\alpha$ and that the macroeconomic state is low so that the government needs to monitor the banks. Then the government works as the banker of a Big Bank. It closes a fraction $\mathrm{x}$ of the banks and taxes some of the (1-x) non-liquidated banks while subsidizing the other nonliquidated banks. In doing so, the government has to meet its budget constraint:

$\alpha+(1+\beta-\alpha) x Q+(1+\beta-\alpha)(1-\mathrm{x})(\pi+(1+\mathrm{x}) \mathrm{M}) \geq 1+\mathrm{f}(1+\beta-\alpha)(1-\mathrm{x})(\pi+(1+\mathrm{x}) \mathrm{M})+\mathrm{C}$. 
The left-hand side consists of three parts: reserve $\alpha$, liquidation proceeds $(1+\beta-\alpha) x Q$, and the cash flow from non-liquidated banks $(1+\beta-\alpha)(1-\mathrm{x})(\pi+(1+x) \mathrm{M})$. The right-hand side also consists of three parts: the one unit promised payment to depositors, a payoff to the non-liquidated banks $\mathrm{f}(1+\beta-\alpha)(1-\mathrm{x})(\pi+(1+\mathrm{x}) \mathrm{M})$, and the government's monitoring cost $\mathrm{C}$. We make the following assumption on information collection cost $C$ to ensure that there is a unique $x \in[0,1]$ that solves the above equation whenever some banks have incentives to engage in fraud.

Assumption 5. $(1-\mathrm{f})(1+\beta) \mathrm{M}<\mathrm{C}<(1+\beta) \mathrm{Q}-1$

At date 1, the government chooses $\mathrm{x}$, the fraction of banks to liquidate, to solve the following problem:

$$
\begin{aligned}
& \operatorname{Max}_{\mathrm{x}} \alpha+(1+\beta-\alpha) \mathrm{xQ}+(1+\beta-\alpha)(1-\mathrm{x})(\pi+(1+\mathrm{x}) M)-\mathrm{C} \\
& \text { s.t. } \quad \alpha+(1+\beta-\alpha) x Q+(1+\beta-\alpha)(1-\mathrm{x})(\pi+(1+x) \mathrm{M}) \geq 1+\mathrm{f}(1+\beta-\alpha)(1-\mathrm{x})(\pi+(1+x) \mathrm{M})+\mathrm{C} \\
& \quad \mathrm{x} \in[0,1] .
\end{aligned}
$$

The solution is given by:

Lemma 3: There is a unique $\mathrm{x} \in[0,1]$ that solves the above problem. The unique solution is:

$$
x=\frac{Q-(1-f) \pi-\sqrt{(Q-(1-f) \pi)^{2}-\frac{4 M(1-f)(1+C-\alpha)}{1+\beta-\alpha}+4 M(1-f)^{2}(\pi+M)}}{2 M(1-f)} .
$$

Moreover, $x$ is increasing in $C$.

Proof: See Appendix.

The government's problem at date 0 can now be written as:

$$
\operatorname{Max}_{\alpha} \int_{\pi_{L}}^{\pi^{r}}[\alpha+(1+\beta-\alpha) x Q+(1+\beta-\alpha)(1-x)(\pi+(1+x) M)-1-C] d F(\tilde{\pi})+
$$




$$
\begin{array}{ll} 
& \int_{\pi^{r}}^{\pi_{H}}[\alpha+(1+\beta-\alpha)(\pi+M)-1] d F(\tilde{\pi})+1+\frac{1}{4 \kappa} \\
\text { s.t. } \quad \pi^{\mathrm{r}}=\frac{1-\alpha}{(1-\mathrm{f})(1+\beta-\alpha)} \\
\\
\mathrm{x}=\frac{\mathrm{Q}-(1-\mathrm{f}) \pi-\sqrt{(\mathrm{Q}-(1-\mathrm{f}) \pi)^{2}-\frac{4 \mathrm{M}(1-\mathrm{f})(1+\mathrm{C}-\alpha)}{1+\beta-\alpha}+4 \mathrm{M}(1-\mathrm{f})^{2}(\pi+\mathrm{M})}}{2 \mathrm{M}(1-\mathrm{f})} \\
\alpha \in[0, \bar{\alpha}]
\end{array}
$$

Solving the government's problem gives the following proposition:

Proposition 4: The government's objective function has a unique maximum in the interval $[0, \bar{\alpha}]$. Moreover, if $C$ is small enough, the government's objective function is strictly concave in $\alpha$ and there exists a unique solution, $\alpha \in[0, \bar{\alpha}]$, that solves the government's optimization problem.

Proof: See Appendix.

The central bank deposit insurance works as follows. At date 1, the state of the macroeconomy is realized and the central bank calculates whether there are any banks with an incentive to engage in fraud. If the state of the macroeconomy is low and some banks have incentives to engage in moral hazard, then the central bank monitoring and insurance system is triggered. The central bank first monitors every individual bank to learn the realization of idiosyncratic shocks. Then it closes some of the banks (banks with idiosyncratic shocks in the interval $[0, \mathrm{xM}]$ ), and taxes and subsidizes the remaining banks. Banks with $\mathrm{r}<\frac{1-\alpha}{(1-\mathrm{f})(1+\beta-\alpha)}-\pi$ get subsidized and banks with $r>\frac{1-\alpha}{(1-f)(1+\beta-\alpha)}-\pi$ get taxed. The final payoff to liquidated banks is equal to zero and to non-liquidated banks with idiosyncratic shock $r$ is equal to $f(1+\beta-\alpha)(\pi+r)$. The information collection $\operatorname{cost} \mathrm{C}$ is paid from the liquidation proceeds and taxes.

Finally, we need to find out whether the government should provide deposit insurance to get rid of panics. This can be done by comparing the social welfare under the required reserve system with the social welfare under the deposit insurance system. 
Proposition 5: The smaller the information collection cost $C$ and the traveling cost $\kappa$ are, the more likely that government deposit insurance is preferred.

Proof: See Appendix.

\section{Conclusion}

Banking panics are not an inherent feature of banks. Rather, panics occur in certain kinds of banking systems. Banking panics can cause incentive compatible private bank coalitions to arise to issue private coalition money, a sort of deposit insurance and lender-of-last-resort. These points were made by Gorton and Huang (2001). We extend their model to show how government intervention into the banking system may be justified when the industrial organization of the banking system is such that there are many small, independent, unit banks. Bank liabilities, bank notes and bank deposits, function as a transaction medium. But, when there is a panic, this transactions system is disrupted, causing a loss of welfare. Banks do not take this cost into account when they organize their coalition. The government, however, can take this cost into account. If the government can monitor banks at a sufficiently low cost, then a system of deposit insurance can improve welfare. This is the origin of the lender-of-last-resort role of the government. 


\section{Appendix}

Proof of Proposition 2: The central bank's optimization problem is:

$$
\begin{gathered}
\operatorname{Max}_{\alpha} \int_{\pi_{L}}^{\pi^{r}}[\alpha+(1+\beta-\alpha) x Q+(1+\beta-\alpha)(1-x)(\pi+(1+x) M)-1] d F(\tilde{\pi})+ \\
\int_{\pi^{r}}^{\pi_{H}}[\alpha+(1+\beta-\alpha)(\pi+M)-1] d F(\tilde{\pi})+1+\frac{(1-\eta)^{2}}{4 \kappa} \\
\text { s.t. } \quad \pi^{\mathrm{r}}=\frac{1-\alpha}{(1-\mathrm{f})(1+\beta-\alpha)} \\
\quad \mathrm{x}=\max \left\{0, \min \left\{1, \frac{1-\alpha-\pi(1-\mathrm{f})(1+\beta-\alpha)}{\mathrm{M}(1-\mathrm{f})(1+\beta-\alpha)}-1\right\}\right\} . \\
\eta=\mathrm{A}\left(\pi^{\mathrm{r}}-\pi_{\mathrm{L}}\right)=\mathrm{A}\left(\frac{1-\alpha}{(1-\mathrm{f})(1+\beta-\alpha)}-\pi_{\mathrm{L}}\right) \\
\alpha \in[0, \quad \bar{\alpha}] .
\end{gathered}
$$

Rewrite the objective function as $\mathrm{G}(\alpha)+\mathrm{H}(\alpha)$, where:

$$
\begin{aligned}
& G(\alpha)=\int_{\pi_{L}}^{\pi^{r}}[\alpha+(1+\beta-\alpha) x Q+(1-x)(\pi+(1+x) M)-1] d F(\tilde{\pi})+ \\
& \qquad \int_{\pi^{r}}^{\pi_{H}}[\alpha+(1+\beta-\alpha)(\pi+M)-1] d F(\tilde{\pi}) \\
& \text { and } \mathrm{H}(\alpha)=1+\frac{(1-\eta)^{2}}{4 \kappa}=1+\frac{\left(1-\mathrm{A}\left(\pi^{\mathrm{r}}-\pi_{\mathrm{L}}\right)\right)^{2}}{4 \kappa} .
\end{aligned}
$$

From the proof of the private coalition's problem (see Gorton and Huang (2001)), we know that $\mathrm{G}(\alpha)$ is a concave function in $\alpha$. We now show $\mathrm{H}(\alpha)$ is convex in $\alpha$.

Since $\frac{\mathrm{d} \pi^{\mathrm{r}}}{\mathrm{d} \alpha}=\frac{-\beta}{(1-f)(1+\beta-\alpha)^{2}}<0, \quad \frac{\mathrm{d}^{2} \pi^{\mathrm{r}}}{\mathrm{d} \alpha^{2}}=\frac{-2 \beta}{(1-f)(1+\beta-\alpha)^{3}}<0$, we have

$$
\begin{aligned}
& H^{\prime}(\alpha)=-\frac{1}{2 \kappa} A\left(1-\mathrm{A}\left(\pi^{\mathrm{r}}-\pi_{\mathrm{L}}\right)\right) \frac{\mathrm{d} \pi^{\mathrm{r}}}{\mathrm{d} \alpha}>0 \\
& \mathrm{H}^{\prime}(\alpha)=\frac{1}{2 \kappa} \mathrm{A}^{2}\left(\frac{\mathrm{d} \pi^{\mathrm{r}}}{\mathrm{d} \alpha}\right)^{2}-\frac{1}{2 \kappa} \mathrm{A}\left(1-\mathrm{A}\left(\pi^{\mathrm{r}}-\pi_{\mathrm{L}}\right)\right) \frac{\mathrm{d}^{2} \pi^{\mathrm{r}}}{\mathrm{d} \alpha^{2}}>0 .
\end{aligned}
$$


Therefore the objective function $\mathrm{G}(\alpha)+\mathrm{H}(\alpha)$ is not necessarily concave. However, since $\mathrm{G}(\alpha)+\mathrm{H}(\alpha)$ is continuous in $[0, \bar{\alpha}]$, and it has a finite value when $\alpha=0$ and $\alpha=\bar{\alpha}$, there is a finite maximum in the interval $[0, \bar{\alpha}] . \mathrm{G}^{\prime \prime}(\alpha)+\mathrm{H}^{\prime \prime}(\alpha)<0$ when $\kappa$ is sufficiently large enough. Therefore there can be a unique interior optimal reserve level, $\alpha \in[0, \bar{\alpha}]$, that solves the coalition's optimization problem. //

Proof of Proposition 3: The optimal reserve level for the private coalition $\alpha^{\mathrm{C}}$ is feasible for the central bank. When $\alpha<\alpha^{\mathrm{C}}$, we have $\mathrm{G}(\alpha)<\mathrm{G}\left(\alpha^{\mathrm{C}}\right)$ because $\mathrm{G}(\alpha)$ reaches its maximum at $\alpha^{\mathrm{C}}$, and we also have $H(\alpha)<H\left(\alpha^{\mathrm{C}}\right)$ because $H(\alpha)$ is increasing in $\alpha$. Therefore, the optimal reserve level under central bank intervention is always higher than the one under the private coalition and the central bank intervention with the required reserve level dominates the private coalition. //

Proof of Lemma 3: Let $F(x)=\alpha+(1+\beta-\alpha) x Q+(1+\beta-\alpha)(1-f)(1-x)(\pi+(1+x) M)-1-C$.

$F(x)$ is a continuous quadratic function of $x$. By assumption 5 we have $F(0)<0$ and $F(1)>0$. Therefore, there exists solutions in the interval $[0,1]$ for the equation $F(x)=0$. The solution is the smaller root of the quadratic equation, which is:

$x=\frac{Q-(1-f) \pi-\sqrt{(Q-(1-f) \pi)^{2}-\frac{4 M(1-f)(1+C-\alpha)}{1+\beta-\alpha}+4 M(1-f)^{2}(\pi+M)}}{2 M(1-f)} \cdot$ Note that since $\frac{4 M(1-f)(1+C-\alpha)}{1+\beta-\alpha}$ is increasing in $\mathrm{C}, \mathrm{x}$ is increasing in $\mathrm{C} . / /$ 
Proof of Proposition 4: The Central Bank's problem at date 0 is:

$$
\begin{aligned}
& \operatorname{Max}_{\alpha} \int_{\pi_{L}}^{\pi^{r}}[\alpha+(1+\beta-\alpha) x Q+(1+\beta-\alpha)(1-x)(\pi+(1+x) M)-1-C] d F(\tilde{\pi})+ \\
& \qquad \int_{\pi^{r}}^{\pi_{H}}[\alpha+(1+\beta-\alpha)(\pi+M)-1] d F(\tilde{\pi})+1+\frac{1}{4 \kappa} \\
& \text { s.t. } \quad \pi^{\mathrm{r}}=\frac{1-\alpha}{(1-\mathrm{f})(1+\beta-\alpha)} \\
& \quad \mathrm{x}=\frac{\mathrm{Q}-(1-\mathrm{f}) \pi-\sqrt{(\mathrm{Q}-(1-\mathrm{f}) \pi)^{2}-\frac{4 \mathrm{M}(1-\mathrm{f})(1+\mathrm{C}-\alpha)}{1+\beta-\alpha}+4 \mathrm{M}(1-\mathrm{f})^{2}(\pi+\mathrm{M})}}{2 \mathrm{M}(1-\mathrm{f})} \\
& \quad \alpha \in[0, \quad \bar{\alpha}]
\end{aligned}
$$

Rewrite the objective function as $\mathrm{V}(\alpha)-\mathrm{CA}\left(\pi^{\mathrm{r}}-\pi_{\mathrm{L}}\right)+1+\frac{1}{4 \kappa}$, where:

$$
\begin{gathered}
V(\alpha) \equiv \int_{\pi_{L}}^{\pi^{r}}[\alpha+(1+\beta-\alpha) x Q+(1+\beta-\alpha)(1-x)(\pi+(1+x) M)-1] d F(\tilde{\pi})+ \\
\int_{\pi^{\mathrm{r}}}^{\pi_{\mathrm{H}}}[\alpha+(1+\beta-\alpha)(\pi+\mathrm{M})-1] \mathrm{dF}(\tilde{\pi}) \\
=\alpha+(1+\beta-\alpha)\left(\frac{\pi_{\mathrm{L}}+\pi_{\mathrm{H}}}{2}+\mathrm{M}\right)-\int_{\pi_{\mathrm{L}}}^{\pi^{\mathrm{r}}}(1+\beta-\alpha) \mathrm{x}(\pi+\mathrm{xM}-\mathrm{Q}) \mathrm{dF}(\tilde{\pi})-1 .
\end{gathered}
$$

Also rewrite $x(\alpha)=C_{0}-\left(C_{1}+\frac{C_{2}}{1+\beta-\alpha}\right)^{\frac{1}{2}}$ where:

$C_{0}=\frac{Q-(1-f) \pi}{2 M(1-f)}, \quad C_{1}=\frac{(Q-(1-f) \pi)^{2}-4 M(1-f)+4 M(1-f)^{2}(\pi+M)}{4 M^{2}(1-f)^{2}}$ and

$C_{2}=\frac{4 M(1-f)(\beta-C)}{4 M^{2}(1-f)^{2}}=\frac{\beta-C}{M(1-f)}$. 
We have $\frac{\partial x}{\partial \alpha}=-\frac{C_{2}}{2}\left(C_{1}+\frac{C_{2}}{1+\beta-\alpha}\right)^{-\frac{1}{2}}(1+\beta-\alpha)^{-2}$ and

$$
\begin{aligned}
\frac{\partial^{2} \mathrm{x}}{\partial \alpha^{2}}= & \frac{\mathrm{C}_{2}^{2}}{4}\left(\mathrm{C}_{1}+\frac{\mathrm{C}_{2}}{1+\beta-\alpha}\right)^{-\frac{3}{2}}(1+\beta-\alpha)^{-4}-\mathrm{C}_{2}\left(\mathrm{C}_{1}+\frac{\mathrm{C}_{2}}{1+\beta-\alpha}\right)^{-\frac{1}{2}}(1+\beta-\alpha)^{-3} \\
= & \frac{\mathrm{C}_{2}^{2}}{4}\left(\mathrm{C}_{1}+\frac{\mathrm{C}_{2}}{1+\beta-\alpha}\right)^{-\frac{3}{2}}(1+\beta-\alpha)^{-4}+2(1+\beta-\alpha)^{-1} \frac{\partial \mathrm{x}}{\partial \alpha} . \\
\frac{d V(\alpha)}{d \alpha}= & 1-\left(\frac{\pi_{L}+\pi_{H}}{2}+M\right)+\int_{\pi_{L}}^{\pi^{r}} x(\pi+x M-Q)-\frac{\partial x}{\partial \alpha}(1+\beta-\alpha)(\pi+2 x M-Q) d F(\tilde{\pi})+ \\
& \frac{A \beta}{(1-f)(1+\beta-\alpha)} x\left(\pi^{r}+x M-Q\right) \\
\frac{d^{2} V(\alpha)}{d \alpha^{2}}= & \int_{\pi_{L}}^{\pi^{r}}\left(2 \frac{\partial x}{\partial \alpha}-(1+\beta-\alpha) \frac{\partial^{2} x}{\partial x^{2}}\right)(\pi+2 x M-Q) d F(\tilde{\pi})- \\
& \int_{\pi_{L}}^{\pi^{r}} 2 M(1+\beta-\alpha)\left(\frac{\partial x}{\partial \alpha}\right)^{2} d F(\tilde{\pi})+\frac{2 A \beta}{(1-f)(1+\beta-\alpha)}\left(\pi^{r}+2 x M-Q\right) \frac{\partial x}{\partial \alpha}
\end{aligned}
$$

Because $\frac{\partial \mathrm{x}}{\partial \alpha}<0, \quad 2 \frac{\partial \mathrm{x}}{\partial \alpha}-(1+\beta-\alpha) \frac{\partial^{2} \mathrm{x}}{\partial \mathrm{x}^{2}}<0$, and $\pi+2 \mathrm{Mx}-\mathrm{Q}>0, \quad$ we have $\frac{d^{2} V(\alpha)}{d \alpha^{2}}<0$

Therefore $V(\alpha)$ is a strictly concave function of $\alpha$.

On the other hand, $-\mathrm{CA}\left(\pi^{\mathrm{r}}-\pi_{\mathrm{L}}\right)$ is convex in $\alpha$ because $\pi^{\mathrm{r}}$ is concave in $\alpha$. Therefore, the objective function is concave in $\alpha$ if and only if $\mathrm{C}$ is small enough. Because the objective function is continuous and bounded for $\alpha \in[0, \bar{\alpha}]$, there always exists a unique solution. //

Proof of Proposition 5: Social welfare under the deposit insurance system is decreasing in the information cost C. Social welfare under the required reserve system is independent of the information cost $\mathrm{C}$. Therefore the smaller $\mathrm{C}$ is, the more likely that deposit insurance dominates required reserve. On the other hand, if we fix $\mathrm{C}$ and let the traveling cost, $\kappa$, change, since then the optimal reserve level in the deposit insurance system does not depend on $\kappa$, the difference in optimal social welfare under the two systems is decreasing in $\kappa$. The smaller $\mathrm{k}$ is, the more likely that deposit insurance dominates required reserve. // 


\section{References}

Andrew, A. Piatt (1907), “The Influence of Crops Upon Business in America," Quarterly Journal of Economics 20, 323-353.

Andrew, A. Piatt (1908a), "Hoarding in the Panic of 1907," Quarterly Journal of Economics (February), 290-299.

Andrew, A. Piatt (1908b), "Substitutes for Cash in the Panic of 1907," Quarterly Journal of Economics (August), 487-520.

Beck, Thorsten (no date), "Deposit Insurance as a Private Club: Is Germany a Model?," World Bank mimeo.

Bordo, Michael (1985), “The Impact and International Transmission of Financial Crises: Some Historical Evidence, 1870-1933," Revista di Storia Economica 2, 41-78.

Bordo, Michael (1986), "Financial Crises, Banking Crises, Stock Market Crashes and the Money Supply: Some International Evidence, 1870-1933," in Financial Crises and the World Banking System (The Macmillan Press: London), edited by Forrest Capie and Geoffrey Wood, 190-248.

Bordo, Michael and Angela Redish (1987), "Why Did the Bank of Canada Emerge in 1935?," Journal of Economic History 47, 405-417.

Bordo, Michael, Hugh Rockoff, and Angela Redish (1995), "A Comparison of the Stability and Efficiency of the Canadian and American Banking Systems, 1870-1925," NBER Historical Working Paper \#67.

Bordo, Michael, Hugh Rockoff, and Angela Redish (1994), "The U.S. Banking System from a Northern Exposure: Stability versus Efficiency," Journal of Economic History 54, 325341.

Breckenridge, Roeliff Morton (1910), The History of Banking in Canada (National Monetary Commission, $61^{\text {st }}$ Congress, $2^{\text {nd }}$ Session, Document No. 332, Washington D.C.: Government Printing Office).

Bremer, C.D. (1935), American Bank Failures (New York: Columbia University Press).

Calomiris, Charles (1989), "Deposit Insurance: Lessons from the Record," Federal Reserve Bank of Chicago Economic Perspectives (May/June), 10-30.

Calomiris, Charles (1990), “Is Deposit Insurance Necessary? A Historical Perspective," Journal of Economic History 50, 283-95. 
Calomiris, Charles (1993), "Regulation, Industrial Structure, and Instability in U.S. Banking: An Historical Perspective," in Structural Change in Banking (Business One Irwin: Homewood, Illinois), edited by Michael Klausner and Lawrence White, 19-116.

Calomiris, Charles and Gary Gorton (1991), "The Origins of Banking Panics: Models, Facts, and Bank Regulation," in Glenn Hubbard, editor, Financial Markets and Financial Crises (University of Chicago Press; Chicago), pp. 109-173.

Calomiris, Charles and Charles Kahn (1996), "The Efficiency of Self-Regulated Payments Systems: Learning from the Suffolk System," Journal of Money, Credit, and Banking 28, 766-797.

Calomiris, Charles and Larry Schweikart (1991), "The Panic of 1857: Origins, Transmission, and Containment," Journal of Economic History 51, p. 807-34.

Cannon, James G. (1910), Clearing Houses, U.S. National Monetary Commission, $61^{\text {st }}$ Congress, 2d Session, Doc. No. 491 (Washington D.C.; Government Printing Office).

Capie, Forrest (1997), "The Evolution of Central Banking," chapter in Reforming the Financial System: Some Lessons From History (Cambridge, England: Cambridge University Press).

Chapman, John M, and Ray B. Westerfield (1942), Branch Banking: Its Historical and Theoretical Position in America and Abroad (New York: Harper and Brothers).

Comptroller of the Currency (1920), Annual Report (Washington D.C.: Government Printing Office).

Curtis, C.A. (1931), "Banking Statistics in Canada," Statistical Contributions to Canadian Economic History Vol. 1 (Toronto: Macmillan).

Demirgüç-Kunt, Asli and Tolga Sobaci (2000), "Deposit Insurance Around the World: A Data Base," World Bank mimeo.

Donaldson, R. Glen (1993), "Financing Banking Crises: Lessons form the Panic of 1907," Journal of Monetary Economics 31, 69-95.

Diamond, Douglas and Philip Dybvig (1983), "Bank Runs, Deposit Insurance, and Liquidity," Journal of Political Economy 91, 401-419.

Garcia, Gilian (1999), “Deposit Insurance: A Survey of Best Practices,” International Monetary Fund Working Paper 99/54.

Goodhart, Charles (1985), The Evolution of Central Banks: A Natural Development? (London).

Gorton, Gary (1984), "Private Clearinghouses and the Origins of Central Banking," Federal Reserve Bank of Philadelphia Business Review (January-February), 3-12.

Gorton, Gary (1985), "Clearinghouses and the Origins of Central Banking in the U.S.," Journal of Economic History 45, 277-283. 
Gorton, Gary (1996), "Reputation Formation in Early Bank Note Markets," Journal of Political Economy 104, 346-397.

Gorton, Gary and Donald Mullineaux (1987), "The Joint Production of Confidence: Endogenous Regulation and the $19^{\text {th }}$ Century Commercial Bank Clearinghouse," Journal of Money, Credit, and Banking 19, 457-468.

Gorton, Gary and George Pennacchi (1990), "Financial Intermediaries and Liquidity Creation," Journal of Finance 45, 49-72.

Gorton, Gary and Andrew Winton (2001), "Financial Intermediation," Chapter in North-Holland Handbook of the Economics of Finance, edited by George Constantinides, Milton Harris, and René Stulz (forthcoming).

Haubrich, Joseph (1990), "Nonmonetary Effects of Financial Crises: Lessons from the Great Depression in Canada," Journal of Monetary Economics 25, 223-252.

Jayanti, S.V., Ann Marie Whyte, and A. Quang Do (1993), "Bank Failures and Contagion Effects: Evidence from Britain, Canada and Germany," Cleveland State University, unpublished working paper.

Kemmerer, E.M. (1911), Seasonal Variations in the Relative Demand for Money and Capital in the United States, U.S. National Monetary Commission, $61^{\text {st }}$ Congress, $2 \mathrm{~d}$ Session, Doc. No. 588 (Washington D.C.; Government Printing Office).

Livingston, James (1986), Origins of the Federal Reserve System: Money, Class, and Corporate Capitalism, 1890-1913 (Ithaca: Cornell University Press).

Lovell, Michael (1957), "The Role of the Bank of England as Lender of Last Resort in the Crises of the Eighteenth Century," Explorations in Entrepreneurial History 10, 8-21.

Lucas, Robert E. (1980), "Equilibrium in a Pure Currency Economy," in Models of Monetary Economics, edited by John H. Kareken and Neil Wallace (Federal Reserve Bank of Minneapolis: Minneapolis, MN).

McGrane, Reginald (1924), The Panic of 1837: Some Financial Problems of the Jacksonian Era (Chicago: University of Chicago Press).

Miron, Jeffrey (1986), "Financial Panics, the Seasonality of the Nominal Interest Rate and the Founding of the Fed," American Economic Review 76, 125-140.

Moen, Jon and Ellis Tallman (1992), "The Bank Panic of 1907: The Role of Trust Companies," Journal of Economic History 52, 611-630.

Moen, Jon and Ellis Tallman (2000), "Clearinghouse Membership and Deposit Contraction during the Panic of 1907," Journal of Economic History 60, 145-163.

Noyes, Alexander D. (1909), “A Year After the Panic of 1907," Quarterly Journal of Economics 23, p. $185-212$. 
Rolnick, Arthur, Bruce Smith, and Warren Weber (1998a), "Lessons from a Laissez-Faire Payments System: The Suffolk Banking System (1825-58)," Federal Reserve Bank of St. Louis Review 80, 105-116.

Rolnick, Arthur, Bruce Smith, and Warren Weber (1998b), "The Suffolk Bank and the Panic of 1837: How a Private Bank Acted as a Lender-of-Last-Resort," Federal Reserve Bank of Minneapolis, Working Paper No. 592.

Smith, Vera (1936), The Rationale for Central Banking (London).

Sprague, O.M.W. (1910), History of Crises Under the National Banking System (Government Printing Office: Washington D.C.).

Timberlake, Richard (1984), "The Central Banking Role of Clearinghouse Associations," Journal of Money, Credit, and Banking 16, 1-15.

Timberlake, Richard (1987), The Origins of Central Banking in the United States (Cambridge: Harvard University Press).

Vreeland, Edward, John Weeks, and Robert Bonynge (1910), Interviews on the Banking and Currency Systems of Canada (National Monetary Commission, 61 ${ }^{\text {st }}$ Congress, $2^{\text {nd }}$ Session, Senate Document 584, Washington D.C.: Government Printing Office).

Wallace, Neil (1988), "Another Attempt to Explain an Illiquid Banking System: The Diamond and Dybvig Model With Sequential Service Taken Seriously," Federal Reserve Bank of Minneapolis Quarterly Review, 3-15.

Watts, George (1972), “The Origins and Background of Central Banking in Canada,” Bank of Canada Review (May).

White, Eugene N. (1983), The Regulation and Reform of the American Banking System, 19001929 ((Princeton: Princeton University Press).

White, Eugene N. (1984), “A Reinterpretation of the Banking Crisis of 1930," Journal of Economic History 44, 119-138.

Whitney, D. R. (1878), The Suffolk Bank (Cambridge, Massachusetts: Riverside Press).

Wicker, Elmus (1980), “A Reconsideration of the Causes of the Banking Panic of 1930,” Journal of Economic History 40, 571-583.

Wicker, Elmus (1996), The Banking Panics of the Great Depression (Cambridge University Press).

Wicker, Elmus (2000), Banking Panics of the Gilded Age (Cambridge University Press).

Williamson, Stephen (1989), "Bank Failures, Financial Restrictions, and Aggregate Fluctuations: Canada and the United States, 1870-1913," Federal Reserve Bank of Minneapolis Quarterly Review (Summer), 20-40. 
* Thanks to Eslyn Jean-Baptiste, Michael Bordo, John Boyd, Ed Green, and participants at the Federal Reserve Bank of Cleveland Conference on the Origins of Central Banking for comments and suggestions.

${ }^{1}$ Suppose the banker has reserves of $\alpha$ and the realized idiosyncratic shock is $r=0$. The realized state of the macroeconomy is $\pi$. If the banker does not engage in fraud, he earns $\pi(1+\beta-\alpha)+\alpha-1$. If he engages in fraud he earns $\pi f(1+\beta-\alpha)$, since he cannot steal anything from the reserves. If $\pi f(1+\beta-\alpha)>\pi(1+\beta-\alpha)+\alpha-1$, or $\pi<\frac{1-\alpha}{(1-f)(1+\beta-\alpha)}$, the banker engages in fraud. Otherwise he has no incentive to engage in fraud.

${ }^{2}$ At date 1 , each member bank of the coalition holds reserves of $\alpha$ when the state of the economy $\pi$ is realized. If $\pi \geq \frac{1-\alpha}{(1-f)(1+\beta-\alpha)}$, then even the bank with the lowest idiosyncratic shock (i.e., $r=0$ ) has no incentive to engage in fraud. Hence there is no need for depositors to run the banks. If $\pi<\frac{1-\alpha}{(1-f)(1+\beta-\alpha)}$, then some banks have an incentive to engage in fraud.

${ }^{3}$ In order to prevent a banker with idiosyncratic shock $r$ from engaging in fraud, the coalition has to promise him a payoff of at least $\mathrm{f}(1+\beta-\alpha)(\pi+\mathrm{r})$. Therefore, in order to convince depositors that their deposits are safe if they accept clearinghouse loan certificates, the coalition has to satisfy the following condition: $\int_{x 2 M}^{2 M}(\alpha+(1+\beta-\alpha)(\pi+r)-1) d F(\widetilde{r}) \geq \int_{x 2 M}^{2 M} f(1+\beta-\alpha)(\pi+r) d F(\widetilde{r})$. Solving for $x$, we can rewrite the condition as: $x \geq \frac{1-\alpha-\pi(1-f)(1+\beta-\alpha)}{M(1-f)(1+\beta-\alpha)}-1$. The fraction $x$ is between 0 and 1 . 
Therefore, imposing this condition, in order to convince depositors that the remaining banks have no incentives to engage in fraud, the coalition must liquidate a fraction, $x$, of the member banks such that $x \geq x *(\alpha, \pi) \equiv \max \left\{0, \min \left\{1, \frac{1-\alpha-\pi(1-f)(1+\beta-\alpha)}{M(1-f)(1+\beta-\alpha)}-1\right\}\right\}$. 